Lazar Milenković ${ }^{1}$

Tamara Rađenović ${ }^{2}$

Anđelija Baljošević ${ }^{3}$

University of Niš, Faculty of Occupational Safety
P. $49-60$

REVIEW PAPER

DOI: $10.5937 / \mathrm{ESD} 2102049 \mathrm{M}$

Received: March 5, 2021

Accepted: May 14, 2021

\title{
THE IMPORTANCE OF WASTEWATER TREATMENT PLANTS FOR SUSTAINABLE DEVELOPMENT
}

\begin{abstract}
The concept of sustainable development has gained in its importance with the attempt to align the goals of economic development with the goals of preserving the quality of living environment. This paper explains the concept of sustainable development and its dimensions, emphasizing its connection with the communal activity of purification and drainage of atmospheric and wastewater. The evidence from the Republic of Serbia regarding wastewater treatment plants and environmental protection costs raises concerns about sustainability issues. Therefore, the aim of the paper is to point out the importance of increasing wastewater treatment plants' capacity and improving their operability, as well as to emphasize the necessity for structural changes of public utility companies to address the identified problems.
\end{abstract}

Key words: wastewater treatment plants, sustainable development, environmental protection costs

JEL classification: Q25, Q53, Q56

\section{ЗНАЧАЈ ПОСТРОЈЕЊА ЗА ПРЕЧИШЋАВАЊЕ ОТПАДНИХ ВОДА ЗА ОДРЖИВИ РАЗВОЈ}

\begin{abstract}
Апстракт
Кониепт одржсвог развоја добија на значају са покушајем да се ускладе иилеви привредног развоја са чииьевима очувања квалитета животне средине. Овај рад објашњава кониепт одрживог развоја и његових димензија, наглашавајући његову повезаност са комуналном делатношћу пречишћавања и одвођења атмосферских и отпадних вода. Подаци за Републику Србију у погледу постројења за пречишћавање отпадних вода и трошкова заштите животне средине подижу забринутост за питања одрживости. У том смислу, ииьь рада је да укаже на значај повећања капачитета постројења за пречишћавање отпадних вода и унапређења њиховог пословања, као и да
\end{abstract}

\footnotetext{
${ }^{1}$ heah.lazar@gmail.com, ORCID ID 0000-0003-2657-8241

${ }^{2}$ tamara.radjenovic@znrfak.ni.ac.rs, ORCID ID 0000-0003-1632-7772

${ }^{3}$ baljosevicandjelija@gmail.com, ORCID ID 0000-0001-6971-7788
} 
истакне неопходност структурних промена јавних комуналних предузећа како би се решили идентификовани проблеми.

Кључне речи: постројења за пречишћавање отпадних вода, одрживи развој, трошкови заштите животне средине

\section{Introduction}

With the growing concerns regarding the environmental issues and survival of the human society, the concept of sustainable development has gained in its significance. It "has emerged as a need to align the goals of technological progress and economic growth and development, with the goal of preserving the quality of the living environment" (Marković et al., 2020, p. 3). Increasing pollution and rapid degradation of living environment, due to excessive production and consumption, has emphasized the need to seriously raise the question regarding the mere survival of the planet and all its inhabitants.

The concept of sustainable development implies satisfying the needs of current generations without endangering the natural systems and environment and jeopardizing the needs of future generations. It has served as a base for the rise of new philosophy and strategy of social development. Hence, starting from 1994, the World Bank has begun convening annual conferences on sustainable development to raise awareness of the importance of this concept and environmental concerns among other institutions and spread it to all parts of society.

As regards the Republic of Serbia, the vision of its sustainable development is focused towards becoming a country with stable macroeconomic environment, developed infrastructure and institutions that meet EU requirements, highly educated population; in which available natural and knowledge-based resources are used in a productive and efficient manner with considerable environmental protection; a state in which entities from private, public and civil sector mutually interact, and where all citizens have identical possibilities (Government of the Republic of Serbia, 2008).

In the combat against environmental pollution, the central role is devoted to wastewater treatment (Qu et al., 2019). Namely, water represents the essence of life and without this natural resource the survival of human society is seriously threatened. As a result of inadequate care for water resources, half of world population does not have sufficient and sustainable water resources, while $20 \%$ does not have access to clean water (Moghaddam et al., 2017, p. 463). The good water quality is a prerequisite for a healthy life. In order to get adequate water quality, it is necessary to perform several levels of purification in the wastewater treatment plants (WWTPs). Wastewater is polluted water produced by various industrial activities and community (Padrón-Páez et al., 2020). WWTPs represent the technology through which the treated water is discharged into the recipients. The technology of these plants is improved by technical and technological achievements. All countries of the world, including the Republic of Serbia, are striving for the most advanced technologies for wastewater treatment, which will reduce the degradation of the environment as much as possible. Hence, wastewater management is an important issue especially for undeveloped and developing countries. Inadequate and 
inefficient wastewater management could cause the serious ecological, environmental and social consequences (Qu et al., 2019).

Considering all this, in the first chapter of the paper, the importance of sustainable development as theoretical concept is pointed out. The second chapter provides an analysis of wastewater in the Republic of Serbia, the third chapter presents a comparative analysis of environmental costs in the Republic of Serbia for the period from 2013-2019. The next chapter connects sustainable development with wastewater treatment plants, after which the wastewater treatment plant of the city of Kruševac is presented as an example of good practice.

\section{The concept of sustainable development}

The concept of sustainable development, or sustainability, is one of the basic concepts of economics of natural resources and the environment. Many different interpretations of this concept can be found in literature, and it is increasingly given importance, which gives it a central place in considering the long-term perspective of the survival and progress of civilization.

Although great environmental debates took place in the 1960s, the very concept of sustainable development was first mentioned almost a decade after the first United Nations Conference on the Environment in Stockholm in 1972, which marked the formation of the United Nations Environmental Program (UNEP). Many organizations, encouraged by the results of the conference, began to deal more actively with the environmental issues, and in that period the idea of sustainable development was born.

The World Commission on Environment and Development was formed by the UN General Assembly in 1983. After 4 years of work, the report "Our Common Future" was published, in which the concept of "sustainable development" gained a broader meaning by the fact that environmental issues of nature conservation were related to social aspects of development, which has become an unavoidable and generally accepted concept.

The World Summit on Sustainable Development was held in Johannesburg in 2002 under the auspices of the UN, at which it was defined that sustainability had three pillars: environmental, economic, and social. With the further development of the concept, in many countries there was a need for additional pillars - institutional and/or cultural, without which the basic three were not applicable in practice.

The economic dimension of sustainable development is based on the effort to increase economic growth, which would increase real wages, and hence reduce poverty in society. A useful definition of unsustainable development could be that it is development after which environmental damage punishes economic growth (Cvetanović \& Mladenović, 2015). Sustainable development strives for economic development, understood in the traditional sense - as an increase in per capita welfare, aligned with the requirements to reduce poverty and injustice, and that the "resource base" of national economies and the world economy must be preserved (Gavrilović \& Jovanović, 1998). The economic dimension of sustainable development increases the production capacities of underdeveloped and transition countries, while imposing rational consumption of natural resources for the developed countries, and hence increasing the efficiency of their use. This dimension also requires internalization of costs, including social and environmental costs (Milutinović, 2004). 
The first development goal, and at the same time the basic precondition for an acceptable quality of life, is equality and understanding of the interdependence of people within the community, which is a postulate of the social dimension of sustainability. Providing education and opportunity to citizens to contribute to the progress of society through their own work represents social equality. The social dimension of sustainable development requires the active political participation of all sectors of society, and the responsibilities of the competent authorities in defining social policy, including solving the problem of social equality and population size. The implementation of the above can be achieved through the education of the local population and social groups in order to independently come with a solution, and thus contribute to a higher standard of living at the national level.

Actions of key importance for achieving the social dimension of sustainable development are achieving equality in income distribution, gender equality, providing basic social goods for all, stabilizing population growth, political responsibility, and participation.

A healthy environment and life on the planet in general are the results of a productive system and infrastructure, which represent a component of the environment in sustainable development. In order to achieve a healthy environment, large investments in the infrastructure are needed, because in that way the necessary quality of goods and services is achieved. The quality of life also depends on the achieved quality of goods and services. The degree of quality that is necessary to achieve allows nature to selfreproduce. The activities that need to be implemented in order to achieve the dimension of environmental protection are: sustainable use of resources, limitation of all forms of pollution, provision and preservation of natural capital, and avoidance of activities and actions that may have a negative impact on the environment, which occur due to insufficient knowledge to anticipate such situations (Milutinović, 2004).

The fourth dimension of sustainable development is the institutional dimension, on the basis of which the "sustainability prism" model was created. The explanation of this model is that the role of the institutional dimension is to provide support and assistance in carrying out activities that belong to other dimensions of sustainable development. This leads us to the conclusion that mutual coordination between all dimensions is necessary, but also the establishment of a balance between them, because in that way the most efficient results are achieved and their policies are realized.

Culture is one of the most important aspects that influences the understanding of values and patterns of behaviour that directly affect the openness, inclusion and cohesion of society, i.e. the quality of life of people generally. When it comes to the connection between culture and the environment, it is pointed out that cultural factors have an extremely large impact on the lifestyle of citizens of a country, their individual behaviour, the attitude towards consumption, as well as values and attitudes related to environmental protection. In the last few years, since culture has been included in the sustainable development goals, a lot of effort has been made to make it the most important dimension of sustainable development. Culture is an indispensable part of both global and development policies of individual countries and therefore it is a significant factor in sustainable development (Cvejić, 2015). 


\section{The analysis of wastewater in the Republic of Serbia}

Wastewater management represents a compound process comprising of wastewater generation, followed by the wastewater collection through the sewerage systems, the wastewater treatment in WWTPs, and the reintegration of by-products into the environment (Cossio et al. 2020, p. 2). Inefficient wastewater management could lead to the serious environmental issues. The reintegration and re-usage of wastewater by-products are crucial for sustainability.

Wastewater is generally collected through the sewerage system. A comparative analysis of European countries with the Republic of Serbia at the level and quality of construction of sewerage systems shows a significant lag of our country behind the European standards. Also, when analysing the application and scope of legislative regulations, the backlog of the Republic of Serbia appears. However, this backlog has been worked on in recent years, as evidenced by the growing percentage of implementation of the European legislation in the field of sewerage systems. As for the amount of investments, based on the conducted analysis, it is expected that they will reach more than 4 billion euros in the next twenty years. It is very important to emphasize the need for a detailed consideration of the interests of economic, environmental and socio-political nature, to determine the priorities for the construction of sewerage infrastructure, the dynamics of their implementation and to define optimal financial programs given that these are funds of great importance.

Based on statistical data of the wastewater analysis, it is determined that the biggest water pollutants are municipal and industrial wastewater, which is discharged directly into the recipients, without any treatment. According to the UNEP estimates, the $90 \%$ of developing world is discharging wastewater directly into environment without any treatment (Malik et al., 2015, p. 173). In the Republic of Serbia, through the primary treatment, about $8 \%$ of municipal wastewater is treated before discharge. The reason for this situation is the small number of wastewater treatment plants that are in operation and that provide an appropriate degree of treatment. Also, an additional problem is the use of outdated technologies, given that the plants in which they are used were built decades ago. Consequently, the WWTPs may discharge partially or completely untreated wastewater into the environment (Malik et al., 2015).

The wastewater treatment comprises of three stages. It is possible to use primary (wastewater moves very slowly through large tanks - primary sedimentation tanks, where $30-50 \%$ of particulate organic matter is deposited on the bottom, fatty and oily substances float to the surface, where they are removed), secondary (reflected through the biochemical process, which takes place under the influence of microorganisms and is used to further remove suspended particles and reduce biochemical oxygen demand BOD), and tertiary treatment (includes filtration of wastewater on sand filters, elimination of phosphorus by chemical treatment and disinfection).

The percentage of the population covered by the wastewater treatment, according to the Statistical Yearbook from 2020, for 2017 was 13.9\%, while in 2018 that percentage was $14.1 \%$, and in $201914.4 \%$. Out of these, only $12.6 \%$ of the population in 2017 was at least connected to secondary treatment, $12.9 \%$ in 2018 , and $13.1 \%$ in 2019 (see Table 1) (SORS, 2020 , p. 269). The tertiary treatment covers only $1.9 \%$, and those are residents connected to the sewage system which drains wastewater to the wastewater treatment plant in Subotica. 
In order for wastewater treatment to be possible, there must be an adequately built wastewater and atmospheric water collection system. However, there is a problem of insufficiently constructed sewerage network, which results in a low level of municipal wastewater collection (Table 1). There is a tendency to increase the coverage of sewage systems. However, that is still insufficient. The amendment of the Law on Public Property gave greater authorization to the units of the autonomous provinces, as well as to the local self-government units (LGUs) in the provision of communal services. As a result, the coverage of the sewerage network has drastically increased, but there is a problem of inadequate wastewater treatment.

Table 1. Indicators of treated wastewater in the Republic of Serbia

\begin{tabular}{|l|c|c|c|}
\hline Indicators & $\mathbf{2 0 1 7}$ & $\mathbf{2 0 1 8}$ & $\mathbf{2 0 1 9}$ \\
\hline Wastewater treated, mil. $\mathrm{m}^{3}$ & 131 & 132 & 94 \\
\hline Primary treatment & 75 & 76 & 23 \\
\hline Secondary treatment & 43 & 42 & 39 \\
\hline Tertiary treatment & 13 & 14 & 32 \\
\hline The length of the public water supply network, km & 43,497 & 44,361 & 46,444 \\
\hline Number of households connected to the water supply & $2,119,103$ & $2,130,462$ & $2,157,004$ \\
\hline Percentage of population connected to water supply & 86.9 & 87.9 & 89.4 \\
\hline The length of the public sewer network, km & 16,725 & 16,851 & 17,435 \\
\hline $\begin{array}{l}\text { Number of households connected to the sewerage } \\
\text { network }\end{array}$ & $1,515,790$ & $1,528,161$ & $1,572,314$ \\
\hline $\begin{array}{l}\text { Percentage of population connected to the sewerage } \\
\text { network }\end{array}$ & 62.2 & 63.0 & 65.2 \\
\hline $\begin{array}{l}\text { Percentage of population covered by wastewater } \\
\text { treatment }\end{array}$ & 13.9 & 14.1 & 14.4 \\
\hline Of these associated at least on the secondary treatment & 12.6 & 12.9 & 13.1 \\
\hline
\end{tabular}

Source: SORS (2020, p. 269)

Existing systems are burdened with wastewater from households to a greater extent than from economic entities. In already built wastewater treatment systems, the problem is system maintenance, improvement of work and quality of treated water. Hence, the environmental problems in the Republic of Serbia are immense, as existing WWTPs do not have capacity to treat the collected wastewater, whereas cities lack funds to adequately maintain and upgrade the existing facilities. With an estimated investment of over several billion euros, the wastewater sector can become one of the development opportunities of our economy that can provide the conditions for job creation.

\section{The analysis of environmental protection costs}

Environmental protection costs are costs incurred in order to prevent, reduce, and eliminate pollution or any other environmental degradation due to the process of production or use of goods and services. Comparative analysis includes costs for air protection, costs of wastewater management, waste management, costs for protection and rehabilitation of land, groundwater and surface water, costs of protection against noise 
and vibration, costs for nature protection and other activities related to environmental protection (Table 2).

Air protection costs in 2015 showed a significant increase compared to other years. For the municipal activity of wastewater management in 2019, significantly higher costs were recorded compared to the observed period from 2013-2019. In relation to the observed costs, the costs of waste management recorded the highest values, and in the observed period, the largest amount was recorded in 2019. Other activities related to environmental protection, which include protection and rehabilitation of land, groundwater and surface water, protection against noise and vibration, nature protection and other activities recorded the highest growth in 2017.

Table 2. Environmental protection costs by activities in the Republic of Serbia in mil. RSD

\begin{tabular}{|l|c|c|c|c|c|c|c|}
\hline & 2013 & 2014 & 2015 & 2016 & 2017 & 2018 & 2019 \\
\hline $\begin{array}{l}\text { Environmental } \\
\text { protection costs }\end{array}$ & $31,306.4$ & $30,509.7$ & $34,826.0$ & $35,349.4$ & $34,402.3$ & $38,266.7$ & $42,367.8$ \\
\hline Air protection & $3,571.2$ & $4,098.7$ & $8,517.1$ & $5,704.2$ & $2,000.5$ & $3,077.5$ & $4,584.2$ \\
\hline $\begin{array}{l}\text { Wastewater } \\
\text { management }\end{array}$ & $4,865.1$ & $4,978.7$ & $4,348.3$ & $4,420.7$ & $4,465.9$ & $4,681.8$ & $5,817.1$ \\
\hline Waste management & $15,827.5$ & $14,349.6$ & $15,309.8$ & $19,390.4$ & $20,236.9$ & $24,434.6$ & $26,307.4$ \\
\hline $\begin{array}{l}\text { Other activities } \\
\text { related to } \\
\text { environmental } \\
\text { protection }\end{array}$ & $7,042.6$ & $7,082.7$ & $6,650.9$ & $5,834.1$ & $7,699.0$ & $6,072.7$ & $5,659.2$ \\
\hline $\begin{array}{l}\text { Environmental } \\
\text { investments }\end{array}$ & $11,707.3$ & $10,041.8$ & $12,292.3$ & $12,805.0$ & $6,592.7$ & $7,437.7$ & $11,606.4$ \\
\hline $\begin{array}{l}\text { Current } \\
\text { environmental } \\
\text { expenditures }\end{array}$ & $19,599.1$ & $20,467.9$ & $22,533.7$ & $22,544.4$ & $27,809.6$ & $30,828.9$ & $30,761.5$ \\
\hline
\end{tabular}

Source: Authors calculated based on various SORS reports - Environmental protection costs in the Republic of Serbia (2013, 2014, 2015, 2016, 2017, 2018, 2019)

Observing the total costs, this analysis determined that their highest amount was recorded in 2019. When we talk about investments for environmental protection, whose structure is the same as the costs, the largest amount of funds for investment in this area was invested in 2016. Current expenditures for environmental protection have shown increasing growth from year to year, and the highest is recorded in 2018.

\section{Linking sustainable development with wastewater treatment plants}

One of the biggest challenges to the concept of sustainable development is the pressure on anthropogenic activities on natural resources, which results in the separation of three crisis areas: providing sufficient food, energy supply, and environmental protection. Water is a renewable resource and its inadequate protection and excessive use cause problems in all these areas. One of the modern technical-technological solutions to this problem is the construction of WWTPs, which drastically reduces the concentration 
of undesirable substances released into the recipients. The result of this process results in the achievement of the sixth global goal of sustainable development - clean water and sanitation, and thus connects all three dimensions of sustainable development with WWTPs. These goals are in effect from 2015-2030 and are promoted by the UN.

The criteria for the assessment of sustainable management of the wastewater treatment system include the ecological, social, and economic aspects of the communal infrastructure. Through these aspects, a satisfactory level of services is provided to all citizens without disrupting the natural, built, and social systems on which the provision of these services depend.

Atmospheric and wastewater treatment and drainage, as one of the communal activities of general interest, must provide basic services that enable economic and social development and at the same time have an impact on the way society treats water as a development resource.

Sustainable development planning implies the establishment of links between land use and resources, air, water and land pollution and waste generation as a consequence of social and economic impacts in the development of urban areas and wider spatial artificial and natural ecosystem units. Urban development is part of the global concept of sustainable development and implies the application of environmental policy with the focus on projects that contribute to reducing resource consumption and minimizing the impact of the industrial and communal sectors on the environment.

\section{The wastewater treatment plant in the city of Kruševac - an example of good practice}

Bearing in mind that water as a natural resource is limited, one of the main goals of conservation and protection of watercourses is the treatment of wastewater from industries and households that are discharged into recipients. The creation of the WWTP project aims to protect and preserve the environment, as well as reduce the negative impact on human health.

Based on research conducted by the Association for Water Technology and Sanitary Engineering (AWTSE), it was found that thirty-three local governments have WWTPs. Seven local governments are with the primary, 21 with the secondary, while 5 units of local governments are with the tertiary treatment. Of all the existing structures and those that are under construction, only 8 of them are in operation, two plants are being reconstructed, five are in trial operation, while eight plants are not working (AWTSE, 2020).

The construction of the WWTP is underway in 13 LGUs. Among those plants are the ones located in Leskovac, Žitiste, Kanjiža, Priboj, Rača, Senjača, Žagubica, Rekovac, Opovo, Vranje, Zrenjanin, Mali Iđoš, and Zlatibor. Some of these plants have reached the final construction stage (AWTSE, 2020).

Improvements in technique and technology, which the process of globalization brings with it, have brought many plants into bankruptcy and liquidation. These plants include: Bačka Topola, Vlasotince, Alibunar, Boljevac, Kanjiža, Sokobanja, and Surdulica. There is a specific example of a WWTP in Medveđa that is currently out of order due to poor location. By changing the location, this plant could be operational (AWTSE, 2020). 
Almost 60 LGUs do not have these facilities, but their construction is planned. As an example of future construction of new plants, there are constructions on the territory of Kuršumlija, the construction of 4 plants is planned, also in Kanjiža, where the construction of two is planned, in addition to two already existing ones, out of which only one is in function. Since the tender documentation for the WWTPs is also necessary, it is being prepared in $6 \mathrm{LGUs}$, the preparation of planning documentation is in progress in 36 LGUs, and 12 units are in the planning phase (AWTSE, 2020).

In 2019, the Ministry of Environment conducted a study, the results of which determined that in addition to the WWTPs mentioned in the AWTSE Survey, there are 14 WWTPs, out of which 8 are in operation, a new plant in Plandište is in the final phase of construction, and 5 plants are not operational: Bela Palanka, Velika Plana, Despotovac, Kladovo, and Ruma (AWTSE, 2020).

In order to increase the efficiency of water resources, ensure the appropriate quality and quantity of drinking water for the population and the economy, as well as wastewater management, the German Development Bank (KfW) has established a program "Program for water supply, wastewater treatment and sewerage in mediumsized cities in Serbia", through which it provides significant financial assistance for the implementation of EU standards in the field of water protection. One of the larger projects financed by this bank is the Kruševac WWTP Project (Ministry of Construction, Transport and Infrastructure, 2019).

The holder of the "Kruševac Wastewater Treatment Plant" Project is the Ministry of Construction, Transport and Infrastructure. This project represents the most significant capital investment in the Rasina district, whose total value amounts to $€ 23,846,000$ including the construction of a city collector network over $40 \mathrm{~km}$ long. The project is financed for the period of 12 years, where $95 \%$ of the loan is repaid by the Government of the Republic of Serbia, while the remaining $5 \%$ is repaid by the public utility company (PUC) "Vodovod Kruševac". The project started on April 25, 2018 and lasted until February 02,2020 , when the trial operation of the plant was completed, and regular activities began. The project consisted of two main activities: (PUC Vodovod-Kruševac, 2020)

- construction and reconstruction of the sewerage network of the city of Kruševac,

- construction of a WWTP for 90,000 population equivalents.

After the completion of the trial operation of the plant on the accounts of the users of the city water supply system in Kruševac, in addition to water consumption and payment of sewage costs, another item was added - wastewater treatment. PUC "Vodovod-Kruševac" announced the introduction of the price of this service immediately after the beginning of the construction of the WWTP. The price of the service is 18.6 RSD/ $\mathrm{m}^{3}$ without VAT, while $20.46 \mathrm{RSD} / \mathrm{m}^{3}$ with VAT. Taking into account that a household with an average water consumption consumes about $15 \mathrm{~m}^{3}$, there is an increase in bills for water services in the amount of about 300 RSD (PUC Vodovod-Kruševac, 2020).

The recommendation of the Gauf Institute, a consulting company that worked on the project construction, was that the price of the service should be $29.37 \mathrm{RSD} / \mathrm{m}^{3}$, while PUC "Vodovod-Kruševac" planned to charge $24.72 \mathrm{RSD} / \mathrm{m}^{3}$. However, it was decided to reduce the operating costs of the plant, so that the price of services would be socially acceptable for the citizens and at the same time cover the minimum operating costs of the plant (PUC Vodovod-Kruševac, 2020) 
After the implementation of the Project, the pollution of the surface, groundwater and land with wastewater contaminated with organic waste has been minimized, which is a significant step towards preserving the environment and human health. With strict respect for the conditions and consent of the competent authorities, organizations and companies, holders of public authorizations, legal regulations, prevention measures, this project has been sustainable and environmentally friendly for the location where it is located and for the city of Kruševac.

\section{Conclusion}

The sustainable development model focuses on satisfying the human needs and overcoming the conflict between economy and ecology (Štrbac et al., 2012). The rapid urbanization has led to the severe pollution and degradation of ecosystems and human health (Cossio et al., 2020), thus emphasizing the need for the adequate wastewater management. Inefficient wastewater management, as a complex process, can lead to the serious environmental issues. This is especially emphasized in developing countries, in which as the consequence of limited financial resources WWTPs with sufficient capacities to adequately treat collected wastewater are lacking.

In the Republic of Serbia, the alignment with Tthe EU legislation in the field of environment and climate change brings great challenges for the state, local governments, public companies, the economy, but also for the citizens themselves. According to the estimates of the National Environmental Protection Program (NEPP), activities and projects aimed at achieving goals in the field of environmental protection could cost the Republic of Serbia between 4 and 4.5 billion euros in the next 15 years. The planned funds are distributed in the areas of: energy (29\%), waste management (24\%), water and wastewater management $(21 \%)$, and environmental protection in the transport sector (12.5\%) (Business Association of Communal Enterprises KOMDEL, 2004).

The major problem in municipal wastewater management is lack of experts of various profiles necessary for a quality and long-term sustainable approach to this problem. To overcome this problem, support for wastewater management is needed as a very important part of environmental protection.

There is a clear need for modernization of PUCs and the need to stop hiring incompetent staff. It is necessary to adjust the prices of communal services, including water, in order for the PUCs to become self-sustaining. Otherwise, financing PUCs becomes a very difficult task for most LGUs. Instead of borrowing from foreign financial institutions, LGUs should strive to use IPA funds, because they represent the most favourable option. However, in order to be able to apply for these funds, it is necessary to submit complex documentation which is a problem for most PUCs and LGUs, due to lack of financial and human resources.

Considering all the above mentioned, the Republic of Serbia will face serious environmental issues in the future regarding water resources. Therefore, determined actions should be taken towards the improvement of the wastewater management process, especially towards the increase of sewerage system coverage and wastewater treatment. 


\section{References}

Association for water technology and sanitary engineering (2020), Mapping of wastewater treatment plants in Serbia, Belgrade

Business Association of Communal Enterprises KOMDEL (2004), Optimal models of transformation and privatization of communal enterprises in Serbia, Belgrade

Cossio et al. (2020), Indicators for sustainability assessment of small-scale wastewater treatment plants in low and lower-middle income countries, Environmental and Sustainability Indicators, 6, 100028, https://doi.org/10.1016/j.indic.2020.100028.

Cvejić, S. (2015), Culture - The Fourth Pillar of Sustainable Development, Center for international relations and sustainable development, Belgrade

Cvetanović, S., Mladenović, I. (2015), Capital Economics and Financing for Development, Niš, Faculty of Economics in Niš

Gavrilović, P. (1998), International business financing, Belgrade, Faculty of Economics in Belgrade

Government of the Republic of Serbia (2008), National Strategy for Sustainable Development, Belgrade

Malik, O. A., Hsu, A., Johnson, L. A., \& de Sherbinin, A. (2015), A global indicator of wastewater treatment to inform the Sustainable Development Goals (SDGs), Environmental Science \& Policy, Vol. 48, pp. 172-185, http://dx.doi. org/10.1016/j.envsci.2015.01.005.

Marković, M., Krstić, B., \& Rađenović, T. (2020). Circular economy and sustainable development. Economics of Sustainable Development, 4(1), 1-9.

Milutinović, S. (2004), Urbanization and sustainable development, Niš, Faculty of Occupational Safety in Niš

Ministry of Construction, Transport and Infrastructure (2019), Project name: Wastewater treatment plant Kruševac, Belgrade

Moghaddam, V. K. et al. (2017), Sustainable development of water resources based on wastewater reuse and upgrading of treatment plants: a review in the Middle East, Desalination and Water Treatment, Vol. 65, pp. 463-473.

Padrón-Páez, J. I., De-León Almaraz, S. \& Román-Martínez, A. (2020), Sustainable wastewater treatment plants design through multi-objective optimization, Computers and Chemical Engineering, 140, 106850, https://doi.org/10.1016/j. compchemeng.2020.106850.

PUC Vodovod-Kruševac (2020), Project: Wastewater collection and treatment plant, Kruševac

Statistical Office of the Republic of Serbia (2020), Statistical Yearbook, Belgrade

Statistical Office of the Republic of Serbia (2020), Environmental protection costs in the Republic of Serbia 2019, Belgrade

Statistical Office of the Republic of Serbia (2019), Environmental protection costs in the Republic of Serbia 2018, Belgrade 
Statistical Office of the Republic of Serbia (2018), Environmental protection costs in the Republic of Serbia 2017, Belgrade

Statistical Office of the Republic of Serbia (2017), Environmental protection costs in the Republic of Serbia 2016, Belgrade

Statistical Office of the Republic of Serbia (2016), Environmental protection costs in the Republic of Serbia 2015, Belgrade

Statistical Office of the Republic of Serbia (2015), Environmental protection costs in the Republic of Serbia 2014, Belgrade

Statistical Office of the Republic of Serbia (2014), Environmental protection costs in the Republic of Serbia 2013, Belgrade

Štrbac, N., Vuković, M., Voza, D. \& Sokić, Miroslav (2012), Sustainable Development and Environmental Protection, Reciklaža i održivi razvoj, No. 5, pp. 18-29.

$\mathrm{Qu}$, J. et al. (2019), Municipal wastewater treatment in China: Development history and future perspectives, Frontiers of Environmental Science \& Engineering, 13, 88, https://doi.org/10.1007/s11783-019-1172-x. 